\title{
Can Alcohol and Obesity be Considered Risk Factors for Diabetes Mellitus? (environmental study)
}

\author{
Ludmila Radkevich ${ }^{1 *}$ and Dariya Radkevich ${ }^{2}$ \\ ${ }^{1}$ Doctor of Biological Sciences, Center for Theoretical Problems of Physicochemical Pharmacology of the Russian Academy of Sciences, Russia \\ ${ }^{2}$ Center for Theoretical Problems of Physicochemical Pharmacology of the Russian Academy of Sciences Russia
}

Submission: August 08, 2021; Published: September 02, 2021

*Corresponding author: Ludmila Radkevich, Doctor of Biological Sciences, Center for Theoretical Problems of Physicochemical Pharmacology of the Russian Academy of Sciences, Russia

\section{Abstract}

Rationale: The literature recognizes a causal relationship between alcohol consumption and the burden of noncommunicable chronic disease (NCD).

Objective: To investigate the relationship between the maximum and minimum consumption of alcoholic beverages (AB) and metabolic syndrome (MS), the burden of diabetes mellitus, pancreatic cancer, nephritis and alcoholism in 158 countries in 2004.

Methods: U-Mann-Whitney test (UMY) and multiple linear regression analysis (MRA) were used for data analysis; GBD databases 2004; FAO 1990-2005.

Results: Studies have shown that the maximum and minimum consumption of alcoholic beverages (AP) in the countries of the world differed 108 times and amounted to 343 grams per person per day, excluding gender and age ( $\mathrm{p} \leq 0.001)$.

The 20 countries with the highest $A B$ versus the 20 countries with the lowest $A B$ were 14 times higher per capita income $(p \leq 0.001)$; the burden of pancreatic cancer is 3.5 times higher in men and women $(p \leq 0.001)$; the burden of alcoholism is 8 times higher for men, 18 times for women ( $\mathrm{p} \leq 0.001$ ); 2 times in men, the burden of diabetes mellitus is 3 times lower in women and the burden of nephritis is 7 times lower in men and women $(\mathrm{p} \leq 0.001)$. In countries with maximum $\mathrm{AB}$, the predictors of metabolic syndrome - MS (\% of men and women in a country with MS impairment) were 2 times higher ( $\mathrm{p} \leq 0.001)$.

Conclusions: In countries with the highest $\mathrm{AB}$ consumption, the burden of alcoholism and pancreatic cancer is several times higher predictors of MS, but the burden of diabetes and nephritis is lower. Gender differences in the studied characteristics are noted. Further research is needed on the nature of the relationship between alcohol consumption and NCD to develop prevention methods.

Keywords: NCD; MS; Alcohol; Diabetes; Pancreatic cancer; Nephritis; Alcoholism; Quality of life

Abbreviations: AB: alcoholic beverages, AP: animal products, BMI: Body Mass Index, BP: blood pressure, CD: Communicable, maternal, perinatal diseases, Chol: blood cholesterol, diabetes mellitus, EEI: Ecological Efficiency Index, FAO: Food and Agriculture Organization of the United Nations, FS: fruits and sweeteners, Glu: blood glucose, HPI: Happiness Index, IHD: Index of Human Development, IPC: per capita income, f: female, LPA: Low physical activity, m: male, NCD: Noncommunicable diseases, CV: cereals and vegetables, RE: Rating Educations, TDC: Total Daily Consumption, UV: Ultraviolet level

\section{Introduction}

Noncommunicable diseases (NCDs) are rapidly increasing. Risk factors for NCDs pose health problems in all countries [1-6]. In $2016,71 \%$ of the 56.9 million deaths worldwide were caused by NCDs [4]. In countries with a high economic status, metabolic syndrome disorders are important: overweight, physical inactivity and unhealthy diet. These risk factors affect $35 \%$ of the population $[2,4,7]$. In countries with low economic status, the main risk factors for NCDs are tobacco smoking and alcohol [46]. Disorders of metabolic syndrome are the main risk factors for cardiovascular, respiratory and neuropsychiatric diseases, cancer and diabetes mellitus (CD1, CD2). The burden of these diseases accounts for $80 \%$ of NCDs [8,9]. Overweight and obesity cause chronic inflammation of the adipose tissue of low severity $[10,11]$. 


\section{Current Research in Diabetes \& Obesity Journal}

Inhibition of chemokines in the hypothalamus of mice converts obese-resistant mice into obese-prone mice [12]. Since the 1990s, the global burden of CD2 has quadrupled and is the ninth leading cause of death in the world [13]. A T2DM epidemic is developing in Asia. China and India are the epicenters of T2DM [13]. The course of T2DM is influenced by excessive alcohol consumption [14]. However, observational studies have shown that moderate alcohol consumption reduces the risk of T2DM $[15,16]$. Observational studies have found a J-shaped relationship between alcohol and the incidence of T2DM. The positive effect of low alcohol doses on the burden of T2DM is associated with improved glycemic control in T2DM [17]. The health benefits of moderate consumption of alcoholic beverages have been studied for several decades. The authors have antioxidant and anti-inflammatory effects of small doses of alcoholic beverages. However, there are no definitive recommendations [18]. There is an intensive search for diets for the prevention and treatment of T2DM. An increase in the proportion of protein in the diet (keto diet) is recommended for weight control and the treatment of T2DM [19]. Thus, MS, including obesity and alcohol abuse, are considered the main risk factors for T2DM and NCDs.

Purpose of the work: to investigate the influence of the maximum and minimum daily consumption of alcoholic beverages in the structure of nutrition in two groups of countries of the world (20 countries each) on MS, the burden of diabetes mellitus, pancreatic cancer, nephritis and alcoholism.

\section{Materials and Methods}

\section{Study design: statistical analysis of observations.}

For the work, a database of the burden of NCDs, diabetes mellitus, pancreatic cancer, nephritis and alcoholism (ICD-10 codes) was compiled for 158 countries. From this base, 2 groups of 20 countries in a group were selected.

Group 1: countries with the highest daily alcohol consumption $(\mathrm{AB})$.

Group 2: countries with a minimum daily consumption of alcoholic beverages AB (List of countries 1).

Disease burden (DALY) data for men and women in 158 countries, standardized by sex and age per 100,000 population, were collected from the 2004 GBD database [20]. To characterize the "quality of life" (QOL) in countries, a number of indicators were used:

a) per capita income (GDP) in 2000-2016 (US dollars per person per year) [21]

b) the geographical position of countries in latitude and the level of ultraviolet radiation in the capital (UV) (J / $\left.\mathrm{m}^{2} 2004\right)$ [22]

c) life expectancy for men and women (2008 and 2016) [23]

d) access to quality medicine, clean water and clean air [24] e) The index of happiness (IH) in 2016 [25]

f) Predictors of metabolic syndrome (MS) - the percentage of men and women in the country with a Body Mass Index (BMI) $\geq 25 \mathrm{~kg} / \mathrm{m}^{2}$ and $\geq 30 \mathrm{~kg} / \mathrm{m}^{2}$

g) blood cholesterol level ( $\mathrm{Chol} \geq 5.0 \mathrm{mmol} / \mathrm{L}$ and $\geq 6.2 \mathrm{mmol}$ / L)

h) blood glucose (Glu $\geq 7.0 \mathrm{mmol} / \mathrm{l})$

i) blood pressure $(\mathrm{BP} \geq 140 / 90 \mathrm{~mm} \mathrm{Hg})$

j) low physical activity (LPA $\leq 60 \mathrm{~min} /$ day of walking) [26]

The daily food intake (TDC) ( $\mathrm{g} /$ person / day) (50 foods) for each country was selected from the FAO database 1992-2005 [27]. The structure of nutrition (NS) of the countries is presented in the form of 4 blocks in absolute and percentage terms of TDC:

a) 1 - products of animal origin (AP)

b) 2 - grains and vegetables (CV); 3 - fruit and sweeteners (FS)

c) 4 - alcoholic beverages (strong alcohol, wine and beer) ( $\mathrm{AB}$ ) [27]

Statistical analysis of the study results was carried out using the Mann-Whitney-Wilcoxon U-test. The central trend in the distribution of data in the sample was represented by the median with a quartile range and mean. The variance of the data in the samples was estimated using the quartile range $(\mathrm{QR})$ between the first and third quartiles ( $25^{\text {th }}$ and $75^{\text {th }}$ percentiles). The level of statistical significance, reflecting the degree of confidence in the conclusion about the differences between indicators of 1 and 2 groups of countries, was assessed for two levels of accuracy:

a) $\mathrm{p} \leq 0.01$ - probability of error $1 \%$;

b) $\mathrm{p} \leq 0.05$ - the probability of an error is $5 \%$.

In multiple comparisons, the Bonferroni correction was also used to assess the significance

of the study results, taking into account two hypotheses $(p \leq 0.025)$. Analysis of the dependence of the burden of NCD and MS on TDC products was performed using multiple linear regression analysis for «independent variables» (MRA). Standardized indicators of the burden of NCD morbidity: diabetes mellitus, pancreatic cancer, nephritis and alcoholism for 2004 [20] and predictors of MS [26] were used as the "dependent variable" of the MRA. The daily blocks ofTDC were used as "independent variables": AP (animal products), CV (cereals and vegetables), FS (fruits and sweeteners), and $\mathrm{AB}$ (alcoholic beverages) of 158 countries (2005) [27]. A step-by-step procedure for including «independent variables» was applied to obtain the best regression equations containing the minimum number of predictors statistically significantly associated with the «dependent variable». The quality of the regression model was assessed using multiple correlation coefficient (R1), determination coefficient (R2), F-distribution, t-tests for regression coefficients, and residual analysis. Residues 


\section{Current Research in Diabetes \& Obesity Journal}

in all models had a normal distribution. Analysis of the values and signs of the coefficients of the $\beta^{*}$ and $\beta$ regression equations made it possible to estimate the contribution of consumption levels of various products to the values of the indicated types of NCD and
MS predictors. Assessed how much the «dependent variable» will change when the «independent variable» is changed by a unit of measurement. All calculations were performed using the Statistica program (version 13). (Table 1).

Table 1: List of Countries 1 and 2 Groups.

\begin{tabular}{|c|c|c|c|c|c|c|c|c|}
\hline \multicolumn{3}{|c|}{ List of Countries 1 and 2 Groups } & \multicolumn{3}{|c|}{ DALY } & \multicolumn{3}{|l|}{ Age st 2004} \\
\hline 1 Group of Countries & Country & $\begin{array}{c}\text { m Diabetes } \\
\text { Mellitus }\end{array}$ & $\begin{array}{l}\text { f Diabetes } \\
\text { Mellitus }\end{array}$ & IPC 2000 & lat $^{\circ}$ & $\mathrm{UV} \mathrm{rad} \mathrm{J} / \mathrm{m}^{2} 2004$ & $\operatorname{lon}^{\circ}$ & AB Amount \\
\hline 1 & Luxembourg & 154 & 169 & 55306 & 50 & 1687 & 6 & 536 \\
\hline 2 & Ireland & 150 & 144 & 30155 & 52 & 1509 & 6 & 493 \\
\hline 3 & Czech Republic & 210 & 176 & 16132 & 50 & 1707 & 14 & 492 \\
\hline 4 & Austria & 284 & 239 & 29301 & 47 & 1888 & 16 & 397 \\
\hline 5 & Germany & 213 & 211 & 27277 & 53 & 1812 & 12 & 374 \\
\hline 6 & Belgium & 168 & 194 & 27967 & 51 & 1645 & 4 & 358 \\
\hline 7 & Denmark & 238 & 214 & 28640 & 56 & 1691 & 9 & 342 \\
\hline 8 & United Kingdom & 163 & 173 & 26031 & 51 & 1576 & - & 338 \\
\hline 9 & Portugal & 339 & 309 & 18872 & 39 & 2585 & 30 & 333 \\
\hline 10 & Croatia & 185 & 157 & 10747 & 45 & 1976 & 16 & 326 \\
\hline 11 & Spain & 254 & 230 & 21517 & 40 & 2705 & 15 & 320 \\
\hline 12 & Australia & 232 & 171 & 26406 & 34 & 3206 & 151 & 305 \\
\hline 13 & Finland & 192 & 187 & 26732 & 61 & 1494 & 25 & 294 \\
\hline 14 & Estonia & 313 & 250 & 9414 & 59 & 1781 & 25 & 293 \\
\hline 15 & Netherlands & 203 & 188 & 31573 & 52 & 1662 & 4 & 291 \\
\hline 16 & Switzerland & 182 & 181 & 35675 & 47 & 2158 & 6 & 270 \\
\hline 17 & Lithuania & 231 & 207 & 8451 & 54 & 1801 & 26 & 269 \\
\hline 18 & United States of America & 374 & 375 & 36450 & 39 & 2736 & 83 & 269 \\
\hline 19 & Slovakia & 261 & 237 & 11348 & 48 & 1795 & 19 & 268 \\
\hline 20 & Slovenia & 272 & 199 & 18036 & 46 & 2256 & 14 & 263 \\
\hline \multicolumn{9}{|l|}{2 group of countries } \\
\hline 1 & United Arab E & 1023 & 1054 & 81819 & 25 & 4862 & 54 & 4 \\
\hline 2 & Nepal & 347 & 377 & 1220 & 27 & 4130 & 84 & 4 \\
\hline 3 & India & 319 & 291 & 1978 & 28 & 4514 & 77 & 4 \\
\hline 4 & Pakistan & 398 & 337 & 2770 & 31 & 4227 & 73 & 4 \\
\hline 5 & Guinea & 416 & 575 & 896 & 10 & 5391 & 165 & 4 \\
\hline 6 & Mali & 505 & 706 & 1160 & 12 & 5617 & 8 & 4 \\
\hline 7 & Tajikistan & 260 & 302 & 935 & 38 & 3538 & 70 & 3 \\
\hline 8 & Myanmar & 346 & 336 & 1036 & 17 & 4565 & 95 & 3 \\
\hline 9 & Brunei & 685 & 716 & 65035 & 5 & 5148 & 115 & 3 \\
\hline 10 & Solomon Islands & 606 & 531 & 1371 & 9 & 4071 & 160 & 3 \\
\hline 11 & Chad & 507 & 679 & 787 & 14 & 5669 & 14 & 3 \\
\hline 12 & Iran & 264 & 479 & 9436 & 36 & 4038 & 59 & 2 \\
\hline 13 & Syrian AR & 401 & 536 & 3497 & 35 & 3501 & 37 & 2 \\
\hline 14 & Kuwait & 591 & 711 & 55421 & 29 & 4214 & 48 & 2 \\
\hline 15 & Indonesia & 533 & 647 & 4602 & 6 & 5220 & 106 & 2 \\
\hline
\end{tabular}




\section{Current Research in Diabetes \& Obesity Journal}

\begin{tabular}{|l|c|c|c|c|c|c|c|c|}
\hline 16 & Sudan & 412 & 496 & 1812 & 19 & 5783 & 37 & 2 \\
\hline 17 & Bangladesh & 320 & 340 & 1301 & 23 & 4029 & 89 & 1 \\
\hline 18 & Yemen & 242 & 334 & 3086 & 13 & 6089 & 44 & 1 \\
\hline 19 & Niger & 520 & 722 & 597 & 13 & 5811 & 2 & 1 \\
\hline 20 & Saudi Arabia & 700 & 748 & 34140 & 21 & 5384 & 39 & - \\
\hline
\end{tabular}

Results

\section{Quality of life in the 1st and 2nd group of countries}

a) In group 1, compared to group 2, per capita income was 14 times and 9 times higher in 2000 and 2016, respectively $(\mathrm{p} \leq 0.001)$ (Table 2).

b) Group 1 of countries is located $30^{\circ}$ north of Group $2(\mathrm{p} \leq 0.001)$.

c) Group 1 is located at 1 time zone, group 2 - at 4 time zone (64을 east longitude) $(\mathrm{p} \leq 0.001)$.

d) In group 1, the level of ultraviolet radiation $\left(\mathrm{J} / \mathrm{m}^{2}\right)$ is 2.7 times lower than in group $2(\mathrm{p} \leq 0.001)$;

e) Group 1 has 6 times higher Prosperity rating ( $\mathrm{p} \leq 0.001)$; the index of happiness is 1.5 times higher $(\mathrm{p} \leq 0.001) ; 1.7$ times lower corruption ( $\mathrm{p} \leq 0.001) ; 6.5$ times higher amicability ( $p \leq 0.001) ; 1.6$ times higher than the Human Development Index ( $\mathrm{p} \leq 0.001) ; 3.4$ times higher environmental efficiency $(\mathrm{p} \leq 0.001)$;

f) 1.4 times better than medicine $(\mathrm{p} \leq 0.001) ; 2.7$ times cleaner water $(p \leq 0.001) ; 12$ times cleaner air $(p \leq 0.001)$; life expectancy for men is 13 years higher and life expectancy for women is 14 years higher $(\mathrm{p} \leq 0.001)$ (Table 2$)$.

g) In group 1 countries, the gender difference in life expectancy is 2 times higher than group $2(\mathrm{p} \leq 0.001)$.

\section{Analysis of the burden of incidence of diabetes mellitus and concomitant NCD in groups 1 and 2 countries using the Mann-Whitney U test}

a) In the $1^{\text {st }}$ group of countries, the total DALY NCD in men is 1.4 times, in women it is 1.5 times lower than in the $2^{\text {nd }}$ group $(\mathrm{p} \leq 0.001)$ (Table 2).

b) In the $1^{\text {st }}$ group of countries, the burden of Diabetes mellitus in the $2^{\text {nd }}$ group of countries is lower for men and 2.7 times for women $(\mathrm{p} \leq 0.001)$.

c) In group 1 countries, the burden of Pancreas cancer in group 2 countries is 3.4 times higher for men and 3.6 times for women $(\mathrm{p} \leq 0.001)$.

d) In 1 group of countries, the burden of Alcohol use disorders is 7.6 times higher for men and 18.3 times for women in 2 groups of countries $(\mathrm{p} \leq 0.001)$.

e) In the $1^{\text {st }}$ group of countries, the burden of Nephritis and nephrosis in the $2^{\text {nd }}$ group of countries is lower for men and
7.9 times for women $(\mathrm{p} \leq 0.001)$ (Table 2$)$.

\section{Analysis of MS predictors in the 1st and 2nd group of countries}

a) In group 1 countries, the percentage of men and women with overweight was 3 and 2 times higher than group 2, respectively (BMI $\geq 25)(p \leq 0.001)$ and $\left(p \leq 0.03^{*}\right)$ with Bonferroni correction (Table 2).

b) In the $1^{\text {st }}$ group of countries, the $\%$ of men and women was 6.3 times higher than the 2 nd group, the percentage of women was 3.6 times, with obesity 6.3 and 3.6 times, respectively $(B M I \geq 50)(p \leq 0.001),(p \leq 0.022)$.

c) In the $1^{\text {st }}$ group of countries, the $\%$ of men and women with hypercholesterolemia was 3.6 and 3.1 times higher, respectively $(\mathrm{Col} \geq 6.2)(\mathrm{p} \leq 0.001)$ and $(\mathrm{p} \leq 0.001)$.

d) In group 1 countries, the percentage of men and women with hyperglycemia was 1.4 and 1.1 times higher than group 2, respectively (Glu $\geq 7.0)(p \leq 0.001)$, $(p=0.9)$.

e) In the $1^{\text {st }}$ group of countries, the $\%$ of men and women with increased blood pressure by 1.3 times and 1.2 times, respectively, (BP $\geq 140 / 90)(p \leq 0.001)$ and $(p \leq 0.001)$ was higher than group 2.

f) Indicators of hypodynamia did not differ between 1 and 2 group of countries (Table 2).

\section{Food structure in the 1st and 2nd group of countries}

\section{Alcohol consumption levels (g / person / day)}

a) In the $1^{\text {st }}$ group of countries in comparison with the $2^{\text {nd }}$ group, the consumption of «Beverages, Alcoholic» was 23 times higher $(\mathrm{p} \leq 0,001)$ (Table 2).

b) In the $1^{\text {st }}$ group of countries in comparison with the $2^{\text {nd }}$ group, the consumption of «Wine» was 654 times higher $(\mathrm{p} \leq 0.001)$.

c) In the $1^{\text {st }}$ group of countries in comparison with the $2^{\text {nd }}$ group, the consumption of «Beer» was 137 times higher $(p \leq 0,001)$.

d) In the $1^{\text {st }}$ group of countries, in comparison with the $2^{\text {nd }}$ group, consumption of $\mathrm{AB}$ amount was 132 times higher $(\mathrm{p} \leq 0,001)$.

e) In the $1^{\text {st }}$ group of countries, in comparison with the 2 nd group, the $\% \mathrm{AB}$ amount in the TDC structure was 50 times higher $(\mathrm{p} \leq 0,001)$ (Table 2). 


\section{Current Research in Diabetes \& Obesity Journal}

Table 2: d Mann-Whitney U Test, Quality of life, metabolic syndrome and the burden of NCDs in groups 1 and 2.

\begin{tabular}{|c|c|c|c|c|c|c|c|}
\hline Variable & $\mathbf{U}$ & $\mathbf{Z}$ & p-value & Median1 & Quartile1 & Median2 & Quartile2 \\
\hline \multicolumn{8}{|l|}{ The quality of life } \\
\hline IPC 2000 & 79,00 & 3,26 & 0,0011 & 26569 & 12644 & 1895 & 5921 \\
\hline IPC 2016 & 73,00 & 3,27 & 0,0011 & 44718 & 18730 & 4730 & 9376 \\
\hline lat $^{\circ}$ & 3,00 & 5,32 & 0,0000 & 50 & 7 & 20 & 16 \\
\hline $\mathrm{UV} \mathrm{rad} \mathrm{J} / \mathrm{m} 204$ & - & $-5,40$ & 0,0000 & 1798 & 533 & 4714 & 1404 \\
\hline $\operatorname{lon}^{\circ}$ & 70,00 & $-3,50$ & 0,0005 & 15 & 18 & 64 & 53 \\
\hline Prosperity Rating & 7,00 & $-5,21$ & 0,0000 & 16 & 17 & 101 & 59 \\
\hline HPI 2016 & 22,00 & 4,60 & 0,0000 & 6,889 & 1,271 & 4,524 & 1,276 \\
\hline RK 2016 & 9,00 & $-4,98$ & 0,0000 & 17 & 28 & 131 & 51 \\
\hline Rpful & 5,00 & $-4,85$ & 0,0000 & 17 & 18 & 110 & 43 \\
\hline IHD & 16,50 & 4,95 & 0,0000 & 0,954 & 0,054 & 0,598 & 0,225 \\
\hline EPI & 11,00 & 5,02 & 0,0000 & 77 & 6 & 33 & 24 \\
\hline ASM 1990 & 19,00 & 4,69 & 0,0000 & 100 & 1 & 69 & 30 \\
\hline ACW 1990 & 17,50 & 4,63 & 0,0000 & 100 & 1 & 27 & 56 \\
\hline Air 2004 & - & $-5,25$ & 0,0000 & 0,000 & 1 & 118 & 271 \\
\hline male life expectancy & 38,00 & 4,37 & 0,0000 & 76 & 3 & 63 & 16 \\
\hline female life expectancy & 2,00 & 5,34 & 0,0000 & 81 & 2 & 67 & 18 \\
\hline \multicolumn{8}{|l|}{ gender } \\
\hline m NCD & 61,00 & $-3,75$ & 0,0002 & 9841 & 1732 & 13593 & 2979 \\
\hline f NCD & 7,00 & $-5,21$ & 0,0000 & 8743 & 1228 & 13418 & 3003 \\
\hline m Diabetes mellitus & 24,00 & $-4,75$ & 0,0000 & 222 & 83 & 414 & 230 \\
\hline f Diabetes mellitus & 8,00 & $-5,18$ & 0,0000 & 197 & 59 & 533 & 370 \\
\hline m Pancreas cancer & - & 5,40 & 0,0000 & 74 & 25 & 22 & 18 \\
\hline f Pancreas cancer & 21,00 & 4,83 & 0,0000 & 51 & 12 & 16 & 18 \\
\hline n Alcohol use disorders & 9,00 & 5,15 & 0,0000 & 832 & 316 & 110 & 179 \\
\hline f Alcohol use disorders & 4,00 & 5,29 & 0,0000 & 183 & 68 & 10 & 22 \\
\hline m Nephritis and nephrosis & 21,00 & $-4,83$ & 0,0000 & 36 & 26 & 223 & 176 \\
\hline f Nephritis and nephrosis & 20,00 & $-4,86$ & 0,0000 & 27 & 17 & 213 & 97 \\
\hline \multicolumn{8}{|l|}{ Metabolic syndrome MS } \\
\hline $\mathrm{m} \mathrm{BMI} \geq 25 \mathrm{~m} / \mathrm{h} 2$ & 62,00 & 3,72 & 0,0002 & 64 & 7 & 21 & 40 \\
\hline $\mathrm{f} \mathrm{BMI} \geq 25 \mathrm{~m} / \mathrm{h} 2$ & 115,00 & 2,09 & 0,0363* & 55 & 8 & 27 & 44 \\
\hline $\mathrm{m} \mathrm{BMI} \geq 30 \mathrm{~m} / \mathrm{h} 2$ & 63,50 & 3,68 & 0,0002 & 25 & 5 & 4 & 15 \\
\hline $\mathrm{f} \mathrm{BMI} \geq 30 \mathrm{~m} / \mathrm{h} 2$ & 115,00 & 2,29 & 0,0223 & 25 & 6 & 7 & 26 \\
\hline $\mathrm{m} \mathrm{Chol} \geq 6.2 \mathrm{mmol} /$ liter & 8,00 & 5,18 & 0,0000 & 18 & 7 & 5 & 4 \\
\hline f Chol $\geq 6.2 \mathrm{mmol} /$ liter & - & 5,40 & 0,0000 & 22 & 6 & 7 & 4 \\
\hline $\mathrm{m} \mathrm{Glu} \geq 7.0 \mathrm{mmol} /$ liter & 103,50 & 2,60 & 0,0094 & 11 & 2 & 8 & 3 \\
\hline f Glu $\geq 7.0 \mathrm{mmol} /$ liter & 199,00 & $-0,01$ & 0,9892 & 8 & 3 & 9 & 3 \\
\hline m BP $\geq 140 / 90$ mm Hg & 30,00 & 4,58 & 0,0000 & 47 & 6 & 36 & 6 \\
\hline f $\mathrm{BP} \geq 140 / 90 \mathrm{~mm} \mathrm{Hg}$ & 49,00 & 4,07 & 0,0000 & 41 & 10 & 34 & 6 \\
\hline
\end{tabular}

IPC: Per Capita Income; Lon: Longitude; Lat: Latitude; UV: Ultraviolet; HPI: Happiness Index; RK: Corruption Rating; Rpful: Peacefulness Rating; HDI: Human Development Index; EPI: Environmental Performance Index; MC: Metabolic Syndrome; BMI - m/h2: Body Mass Index; m: Male, f: Female; The quality of life; Medicine level; Pure water; Fresh air; Life expectancy; Daily burden; Blood cholesterol - mmol / liter; Blood glucose mmol / liter; Arterial blood pressure - mm Hg; Bonferroni correction $p \leq 0.025^{*}$ 


\section{Daily consumption levels of TDC products (grams / person / day)}

a) In group 1 countries, the total TDC was 2.4 times higher than group $2(\mathrm{p} \leq 0.001)$ (Table 1$)$.

b) In the $1^{\text {st }}$ group of countries the consumption of «products of animal origin» - AP ()$(p \leq 0,001)$ was 3.3 times higher than in the $2^{\text {nd }}$ group.

c) In the $1^{\text {st }}$ group of countries the consumption of "red meat" was 5.3 times higher than in the $2^{\text {nd }}$ group $(p \leq 0,001)$.

d) In group 1 countries consumption was 1.3 times higher than group 2 "Grains and vegetables" - CV ( $\leq \leq 0.010)$.

e) In group 1 countries consumption was 1.3 times lower than group 2 «Legumes» $(\mathrm{p} \leq 0.010)$.

f) In group 1 countries consumption was 3.9 times higher than group 2 «Fruit and sweeteners» - FS ( $\mathrm{p} \leq 0.001)$.

g) In group 1 countries consumption was 132 times higher than group 2 «Alcoholic drinks» - AB ( $\mathrm{p} \leq 0.001)$ (Table 1$)$.

\section{Macronutrients}

\section{Common macronutrients in country groups 1 and 2}

a) In the $1^{\text {st }}$ group of countries, the level of total Energy (kcal / person / day) was 1.4 times higher than in the $2^{\text {nd }}$ group $(\mathrm{p} \leq 0,001)$ (Table 1).

b) In the $1^{\text {st }}$ group of countries, the Diversification of Total Energy was 2 times higher than in the $2^{\text {nd }}$ group $(p \leq 0,001)$.

c) In the $1^{\text {st }}$ group of countries, the $\%$ of total carbohydrates in the total Energy was 1.3 times lower than the $2^{\text {nd }}$ group $(\mathrm{p} \leq 0,001)$.

d) In the 1 st group of countries the $\%$ of total Proteins in the total Energy was 1.1 times higher than the $2^{\text {nd }}$ group $(p \leq 0,004)$.

e) In the $1^{\text {st }}$ group of countries, the $\%$ of total Fats in the total Energy was 1.6 times higher than in the $2^{\text {nd }}$ group $(p \leq 0,001)$ (Table 1).

\section{Macronutrients of «animal products» - AP in groups 1 and 2}

a) In the $1^{\text {st }}$ group of countries it was 3.1 times higher than the $2^{\text {nd }}$ group\% of Energy of "products of animal origin" - AP in the total Energy $(\mathrm{p} \leq 0.001)$ (Table 1).

b) In the $1^{\text {st }}$ group of countries it was 2.3 times higher than the $2^{\text {nd }}$ group \% of the Protein Energy of "animal products" - AP in the total Protein Energy ( $\mathrm{p} \leq 0.001)$.

c) In the $1^{\text {st }}$ group of countries it was 2.1 times higher than the $2^{\text {nd }}$ group\% of Fat Energy of "animal products" - AP in the total Fat Energy $(p \leq 0.001)$.

\section{Relationship between NCD Burden and MS Predictors on TDC Product Consumption in Country Groups 1 and} 2

\author{
Linear Multiple Regression Analysis (MRA)
}

a) MRA was carried out for the influence of the «independent variables»: «AP - animal products», «CV - grains and vegetables», «FS - fruits and sweeteners» and «AB - alcoholic beverages» on the «dependent variables»: «NCD», «Diabetes mellitus «,» Nephritis «,» Pancreas cancer «,» Alcohol use disorders «and predictors of MS:» BMI> 25 «,» BMI> 30 «,» Glu> 7.0 «,» Total Energy «, Animal Energy (Table 2).

b) It was found that the highest correlation (R1) and determination (R2) coefficients were under the influence of: «AP» on «Animal Energy» - $(0.9244 ; 0.854)$; «AP» for «Total Energy kk / p / d» - (0.906; 0.822); «AP» for «m BMI> 25» (0.813; 0.661$)$; «AP» for «m BMI> $30 »-(0.777 ; 0.603)$; «CV» for «f NCD»- $(0.754 ; 0.569)$. This indicates that that more than $60 \%$ of the variability of these "dependent variables" can be determined by "animal products -AP" ( $\mathrm{p} \leq 0.001)$.

c) An increase in «AB» (alcoholic beverages) by 10 grams is accompanied by a decrease in «f NCD» by $0.5 \%$; M Diabetes mellitus 1.9\%; F Diabetes mellitus by 1.5\%; M Nephritis by 1.9\%; F Nephritis by 1.9\%; but an increase in «m Pancreas cancer» by $4.6 \%$; F Pancreas cancer by $3 \%$; «M Alcohol use disorders» by 3\%; «F Alcohol use disorders» by $3 \%(\mathrm{p} \leq 0$, 001) (Table 2).

d) An increase of 10 grams in the «independent variable» «FS» (fruit, sweeteners) caused a decrease in the burden of «m NCD» by $1.3 \%$, «f NCD» by $0.8 \%$, as well as an increase in «m BMI> 25» and «f BMI> 25 «by 2.0\%; and «m BMI> 30» by

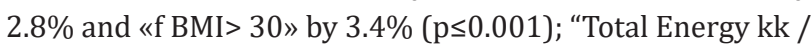
p / d" by $0.9 \%(\mathrm{p} \leq 0.001)$ (Table 2).

e) An increase of 10 grams in the «independent variable» «CV» (grains, vegetables) was accompanied by a decrease in the burden of «f NCD» by $0.1 \%$ and a decrease in the burden of «m Diabetes mellitus» by $0.5 \%$, and «f Diabetes mellitus» by $0,4 \%(\mathrm{p} \leq 0.001)$, a decrease in the burden of «m Nephritis» by $0.5 \%$ and «f Nephritis» $0.6 \%$ ( $\mathrm{p} \leq 0.001)$, but an increase in «m Pancreas cancer» by 2, $0 \%$ and "total Energy kk / p / d" by $0.8 \%$ (Table 3 ).

f) An increase of 10 grams in the «independent variable» «AP» (animal products) resulted in an increase in the «dependent variables» «Animal Energy» by 2\%; Total Energy kk / p / d by $0.2 \%$; predictors of $\mathrm{MS}$ «BMI> $25 »$ and «BMI> $30 »$ by $0.7 \%$, as well as a decrease in the burden of «m Nephritis» by $1.0 \%$ «and» f Nephritis «by $0.6 \%$; but an increase in «f Alcohol use disorders» by $1.0 \%(\mathrm{p} \leq 0,001)$ (Table 4 \& Figures $1-4)$. 


\section{Current Research in Diabetes \& Obesity Journal}

Table 3: Test Mann-Whitney U, Daily food consumption levels; alcohol and macronutrients in groups 1 and 2.

\begin{tabular}{|c|c|c|c|c|c|c|c|}
\hline & $\mathbf{U}$ & $\mathbf{Z}$ & p-value & Median 1 & Quartile1 & Median2 & Quartile2 \\
\hline \multicolumn{8}{|l|}{ Dietary Pattern DP } \\
\hline \multicolumn{8}{|l|}{$\begin{array}{l}\text { "Alcoholic Beverages" - AB gram / } \\
\text { person / day }\end{array}$} \\
\hline Beverages, Alcoholic & - & 5,40 & 0,0000 & 16,4 & 12,50 & 0,7 & 1,00 \\
\hline Wine & - & 5,40 & 0,0000 & 65,4 & 60,00 & 0,1 & 0,00 \\
\hline Beer & - & 5,40 & 0,0000 & 259,8 & 61,00 & 1,9 & 1,50 \\
\hline $\mathrm{AB}$ amount & - & 5,40 & 0,0000 & 341,6 & 85,50 & 2,6 & 2,00 \\
\hline $\mathrm{AB} \% \mathrm{TDC}$ & - & 5,40 & 0,0000 & 15,1 & 3,31 & 0,3 & 0,28 \\
\hline Daily consumption levels TDC & & gram / person / day & & & & & \\
\hline TDC: amount gram / person / day & 2,00 & 5,34 & 0,0000 & 2245 & 235 & 946 & 713 \\
\hline "animal products" - AP & 12,00 & 5,07 & 0,0000 & 810 & 182 & 245 & 337 \\
\hline "grains, vegetables" - CV & 105,00 & 2,56 & 0,0106 & 821 & 115 & 614 & 398 \\
\hline "fruits, sweeteners" - FS & 18,00 & 4,91 & 0,0000 & 268 & 80 & 68 & 139 \\
\hline "alcoholic Beverages" - AB & - & 5,40 & 0,0000 & 323 & 86 & 3 & 2 \\
\hline \multicolumn{8}{|l|}{ TDC:\% } \\
\hline $\mathrm{AP} \% \mathrm{TDC}$ & 118,00 & 2,20 & 0,0275 & 36 & 6 & 25 & 16 \\
\hline CV \% TDC & 26,00 & $-4,69$ & 0,0000 & 37 & 4 & 62 & 16 \\
\hline FS \% TDC & 92,00 & 2,91 & 0,0036 & 12 & 2 & 8 & 7 \\
\hline $\mathrm{AB} \% \mathrm{TDC}$ & - & 5,40 & 0,0000 & 14 & 3 & 0,25 & 0,3 \\
\hline \multicolumn{8}{|l|}{ Common macronutrients } \\
\hline Total Energy kcal / person / day & 19,50 & 4,87 & 0,0000 & 3395 & 430 & 2435 & 760 \\
\hline Carboh \% TE & 8,00 & $-5,18$ & 0,0000 & 52 & 6 & 69 & 8 \\
\hline Proteins \%TE & 93,50 & 2,87 & 0,0041 & 12 & 2 & 11 & 1 \\
\hline Fats \%TE & 6,50 & 5,22 & 0,0000 & 36 & 6 & 22 & 8 \\
\hline \multicolumn{8}{|l|}{ Animal macronutrients } \\
\hline Animal Energy \% TE & 2,50 & 5,33 & 0,0000 & 31 & 6 & 10 & 10 \\
\hline Animal Proteins \% TP & 3,50 & 5,30 & 0,0000 & 61 & 6 & 26 & 22 \\
\hline Animal Fat $\%$ TFat & 16,00 & 4,96 & 0,0000 & 58 & 7 & 27 & 18 \\
\hline \multicolumn{8}{|l|}{ Diversification } \\
\hline DE\%05 & 0,50 & 5,38 & 0,0000 & 70 & 8 & 39 & 19 \\
\hline
\end{tabular}

DP: Dietary Pattern; Daily consumption levels TDC; Overall consumption; AP: Animal Products; AB: Alcoholic Beverages; FS: Fruits \& Sweeteners; CV: Grains \& Vegetables; gram / person / day; kcal / person / day; Diversification; Total Energy kcal / person / day; \% Carbohydrates; \% Proteins; \% Fat; \% animal Energy; \% Animal Proteins; \% animal Fat; Bonferroni correction p $\leq 0,025$

Table 4: Multiple linear regression analysis (MRA) Independent variables: TDC: AP, CV, FS, AB, quantity, disease, DALYs-dependent variables and metabolic syndrome predictors, Energy, AP Energy\%.

\begin{tabular}{|c|c|c|c|c|c|c|c|c|c|c|c|}
\hline DV & INV & R1 & R2 & $b^{*}$ & $\mathrm{~b}$ & T & F & $p$ & DV1 & DV2 & Effect $\%$ \\
\hline m NCD & FS & 0,615 & 0,378 & $-0,615$ & $-17,025$ & $-9,74$ & $\mathrm{~F}(1,156)=94,8$ & 0,0000 & 13071 & 12901 & 98,7 \\
\hline f NCD & CV & 0,754 & 0,569 & $-0,206$ & $-1,631$ & $-3,38$ & $\mathrm{~F}(3,154)=67,8$ & 0,0009 & 11840 & 11823 & 99,9 \\
\hline & FS & & & $-0,388$ & $-9,440$ & $-4,64$ & & 0,0000 & 11840 & 11745 & 99,2 \\
\hline & AB & & & $-0,306$ & $-6,506$ & $-4,02$ & & 0,0001 & 11840 & 11775 & 99,5 \\
\hline
\end{tabular}




\section{Current Research in Diabetes \& Obesity Journal}

\begin{tabular}{|c|c|c|c|c|c|c|c|c|c|c|c|}
\hline m Diabetes mellitus & $\mathrm{CV}$ & 0,457 & 0,209 & $-0,271$ & $-0,165$ & $-3,65$ & $F(2,155)=20,49$ & 0,0004 & 396 & 394 & 99,5 \\
\hline & $\mathrm{AB}$ & & & $-0,300$ & $-0,491$ & $-4,04$ & & 0,0001 & 396 & 391 & 98,7 \\
\hline \multirow[t]{2}{*}{ f Diabetes mellitus } & $\mathrm{CV}$ & 0,560 & 0,314 & $-0,330$ & $-0,252$ & $-4,76$ & $F(2,155)=35,4$ & 0,0000 & 469 & 467 & 99,6 \\
\hline & $\mathrm{AB}$ & & & $-0,370$ & $-0,759$ & $-5,34$ & & 0,0000 & 469 & 462 & 98,5 \\
\hline \multirow[t]{3}{*}{$\begin{array}{l}\text { m Nephritis and } \\
\text { nephrosis }\end{array}$} & $\mathrm{AP}$ & 0,709 & 0,502 & $-0,328$ & $-0,185$ & $-3,55$ & $F(3,154)=51,8$ & 0,0005 & 208 & 206 & 99,0 \\
\hline & $\mathrm{CV}$ & & & $-0,237$ & $-0,114$ & $-3,55$ & & 0,0005 & 208 & 207 & 99,5 \\
\hline & $\mathrm{AB}$ & & & $-0,291$ & $-0,375$ & $-3,50$ & & 0,0006 & 208 & 204 & 98,1 \\
\hline \multirow[t]{3}{*}{$\begin{array}{l}\text { f Nephritis and } \\
\text { nephrosis }\end{array}$} & $\mathrm{AP}$ & 0,757 & 0,572 & $-0,318$ & $-0,128$ & $-3,72$ & $F(3,154)=68,7$ & 0,0003 & 160 & 159 & 99,4 \\
\hline & $\mathrm{CV}$ & & & $-0,225$ & $-0,077$ & $-3,65$ & & 0,0004 & 160 & 159 & 99,4 \\
\hline & $\mathrm{AB}$ & & & $-0,366$ & $-0,336$ & $-4,76$ & & 0,0000 & 160 & 157 & 98,1 \\
\hline \multirow[t]{2}{*}{ m Pancreas cancer } & $\mathrm{CV}$ & 0,743 & 0,552 & 0,262 & 0,023 & 4,68 & $F(2,155)=95,6$ & 0,0000 & 43 & 44 & 102,0 \\
\hline & $\mathrm{AB}$ & & & 0,627 & 0,151 & 11,20 & & 0,0000 & 43 & 45 & 104,6 \\
\hline f Pancreas cancer & $\mathrm{AB}$ & 0,578 & 0,334 & 0,578 & 0,089 & 8,85 & $F(1,156)=78,25$ & 0,0000 & 33 & 34 & 103,0 \\
\hline $\begin{array}{l}\text { m Alcohol use } \\
\text { disorders }\end{array}$ & $\mathrm{AB}$ & 0,441 & 0,194 & 0,441 & 1,789 & 6,14 & $F(1,156)=37,6$ & 0,0000 & 570 & 588 & 103,0 \\
\hline \multirow[t]{2}{*}{$\begin{array}{l}\text { f Alcohol use } \\
\text { disorders }\end{array}$} & AP & 0,655 & 0,429 & 0,337 & 0,121 & 3,85 & $F(2,155)=58,2$ & 0,0002 & 94 & 95 & 101,0 \\
\hline & $\mathrm{AB}$ & & & 0,369 & 0,303 & 4,21 & & 0,0000 & 94 & 97 & 103,0 \\
\hline \multirow[t]{2}{*}{$\mathrm{m} \mathrm{BMI}>25$} & AP & 0,813 & 0,661 & 0,384 & 0,031 & 5,18 & $F(2,155)=151,0$ & 0,0000 & 42,5 & 42,8 & 100,7 \\
\hline & FS & & & 0,478 & 0,101 & 6,45 & & 0,0000 & 42,5 & 43,5 & 102,0 \\
\hline f BMI>25 & FS & 0,604 & 0,364 & 0,604 & 0,110 & 9,43 & $F(1,155)=88,8$ & 0,0000 & 46 & 47 & 102,0 \\
\hline \multirow[t]{2}{*}{$\mathrm{m} \mathrm{BMI}>30$} & $\mathrm{AP}$ & 0,777 & 0,603 & 0,367 & 0,014 & 4,57 & $F(2,155)=117,8$ & 0,0000 & 13,8 & 13,9 & 100,7 \\
\hline & FS & & & 0,457 & 0,045 & 5,70 & & 0,0000 & 13,8 & 14,2 & 102,8 \\
\hline f $\mathrm{BMI}>30$ & FS & 0,547 & 0,299 & 0,547 & 0,067 & 8,15 & $F(1,156)=66,4$ & 0,0000 & 20,5 & 21,2 & 103,4 \\
\hline $\mathrm{m}$ glu $>7.0$ & AP & 0,554 & 0,307 & 0,554 & 0,005 & 8,32 & $F(1,156)=69,2$ & 0,0000 & 9,3 & 9,4 & 101,0 \\
\hline f glu $>7.0$ & $\mathrm{AB}$ & 0,342 & 0,117 & $-0,338$ & $-0,008$ & $-2,80$ & $F(4,153)=5,08$ & 0,0057 & 9,3 & 6,7 & 72,0 \\
\hline \multirow[t]{3}{*}{ total Energy kk/p/d } & AP & 0,906 & 0,822 & 0,271 & 0,543 & 4,89 & $F(3,154)=236,3$ & 0,0000 & 2717 & 2722 & 100,2 \\
\hline & $\mathrm{CV}$ & & & 0,320 & 0,547 & 7,99 & & 0,0000 & 2717 & 2722 & 100,2 \\
\hline & FS & & & 0,466 & 2,453 & 8,51 & & 0,0000 & 2717 & 2741 & 100,9 \\
\hline animal Energy \% & AP & 0,924 & 0,854 & 0,924 & 0,034 & 30,18 & $F(1,156)=910,6$ & 0,0000 & 16,9 & 17,3 & 102,0 \\
\hline
\end{tabular}

NCD: Non-Communicable Diseases; TDC: Total Daily Food Intake (g/p/d); AP: Animal Products (g/p/d); DALY: Disability-Adjusted Life Year; CV: Grains, Vegetables (g/p/d); FS: Fruits, Sweeteners (g/p/d); AB: Alcoholic Drinks (g/p/d); DV1: Dependent Variable 1; DV2: Dependent Variable 2

Bonferroni amendment

R1: коэффрициент корреляции; R2: коэффрициент детерминации; b*: стандартизированный коэффрициент; b: коэфффициент регрессии 


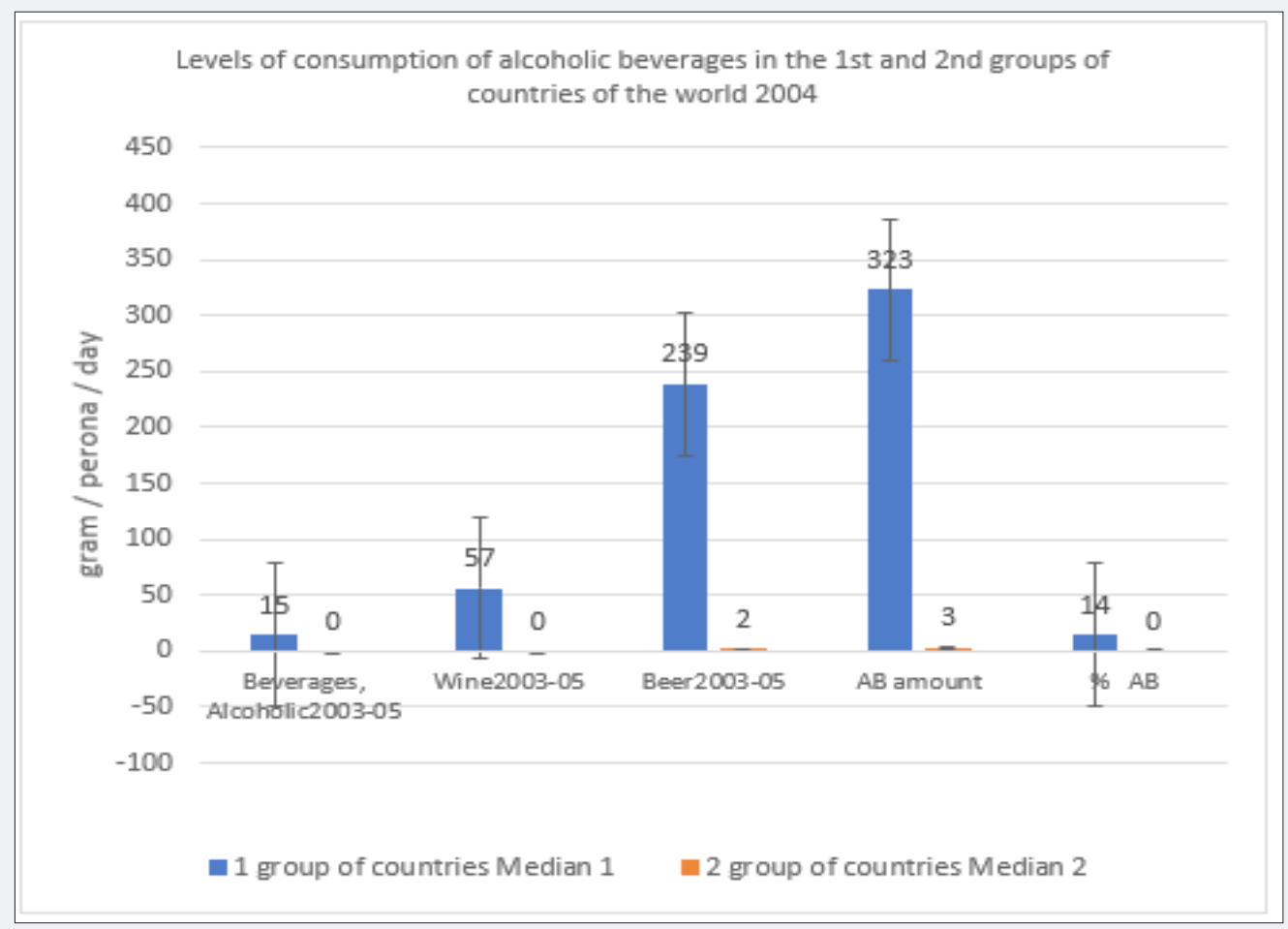

Figure 1: Levels of consumption of alcoholic beverages in the $1^{\text {st }}$ and $2^{\text {nd }}$ group of countries.

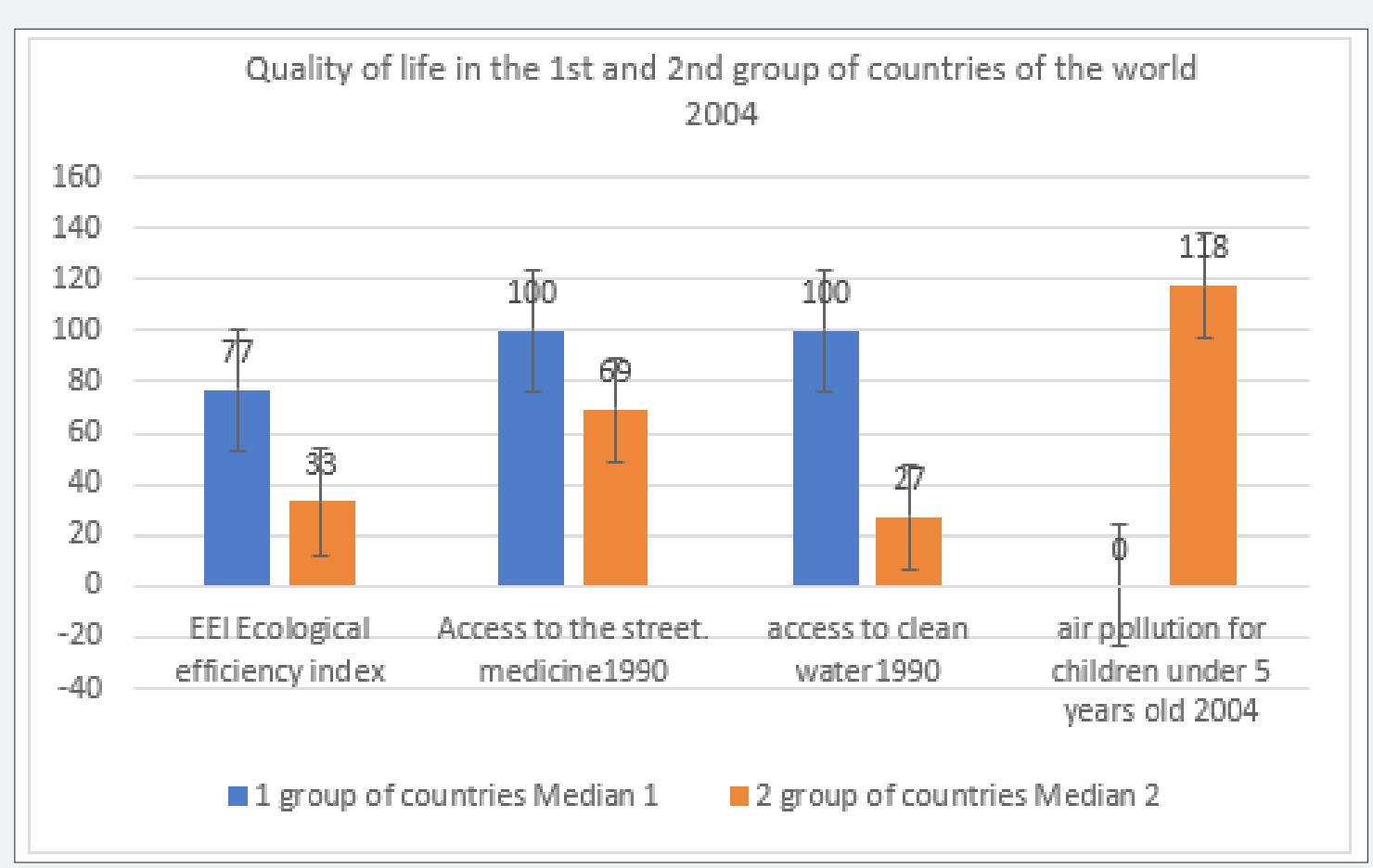

Figure 2: Characteristics of the quality of life in the $1^{\text {st }}$ and $2^{\text {nd }}$ group of countries. 


\section{Current Research in Diabetes \& Obesity Journal}

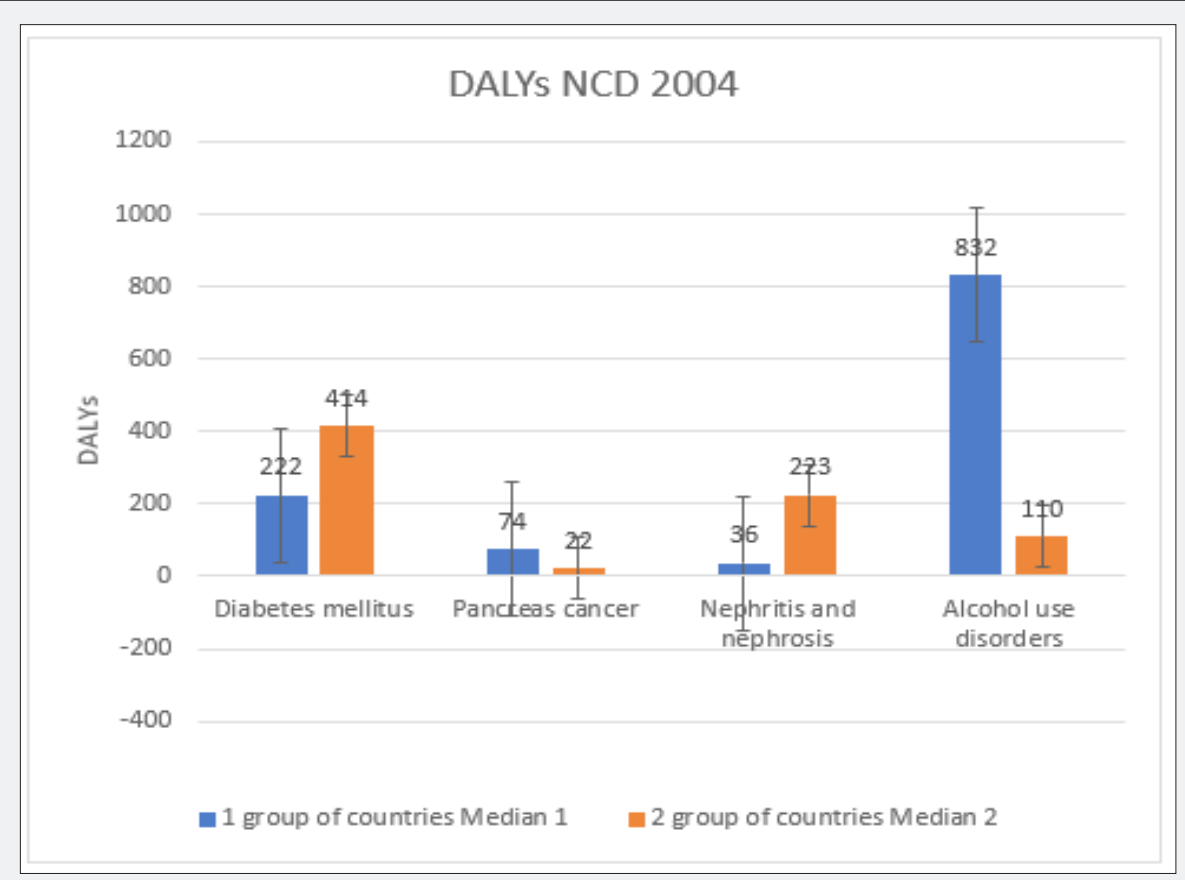

Figure 3: Burdens of diabetes, pancreatic puck, nephritis and alcoholism in groups 1 and 2.

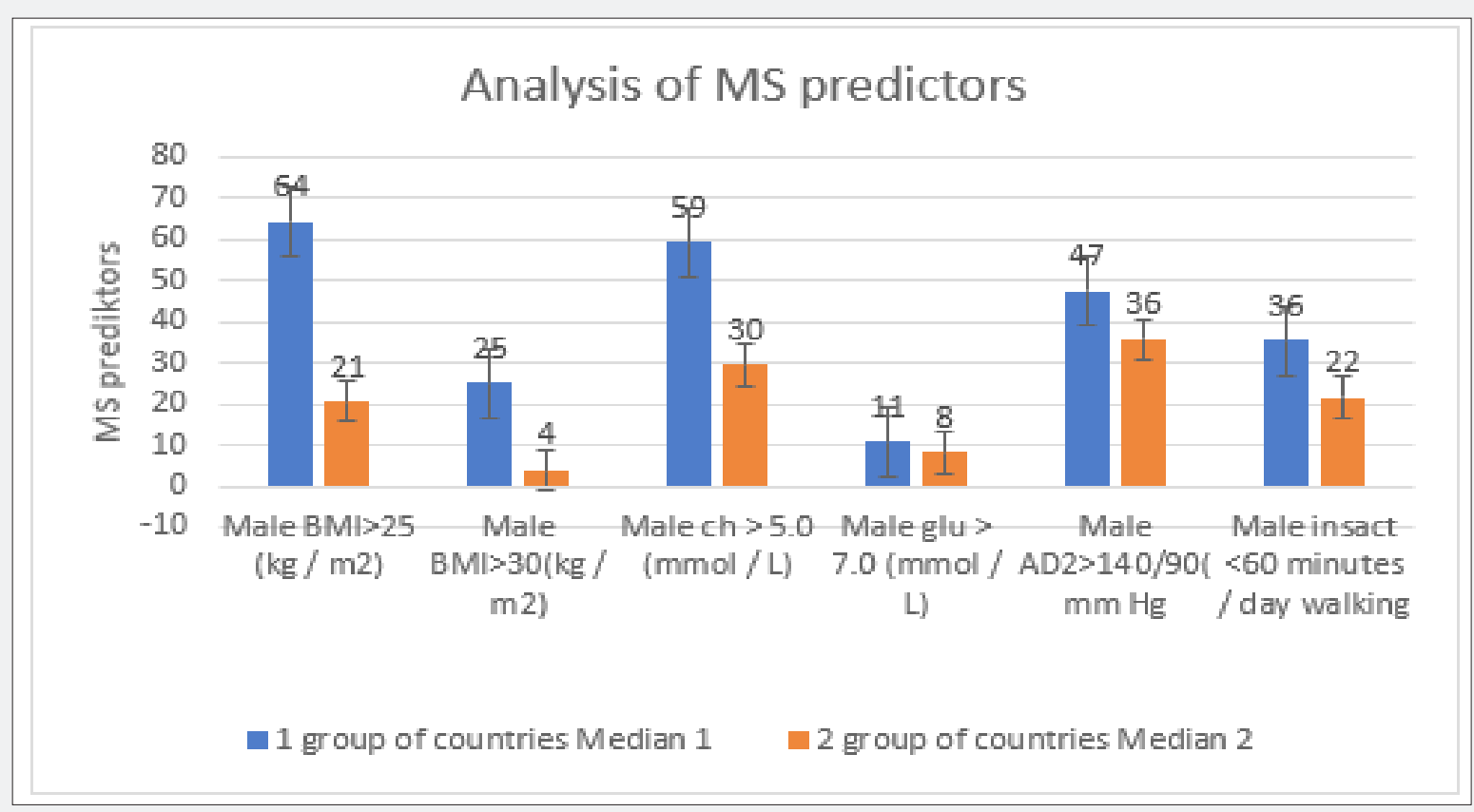

Figure 4: Predictors of metabolic syndrome in countries 1 and 3.

\section{Discussion}

As a result of the research, it was found that in the 1st group of countries the total consumption of alcoholic beverages (AB) was 132 times higher than in the $2^{\text {nd }}$ group of countries. In the $1^{\text {st }}$ group of countries, the consumption of strong alcohol was
23 times higher, the consumption of wine was 654 times and the consumption of beer was 137 times higher. In the $1^{\text {st }}$ group of countries, the share of hard alcohol was $4.8 \%$ versus $27 \%$ in the 2 nd group ( $\mathrm{p} \leq 0.001)$. In the $1^{\text {st }}$ group of countries, the share of wine was $19 \%$ versus $1.9 \%$ in the 2 nd group ( $p \leq 0.001)$. The 
share of beer in groups 1 and 2 was 70\%. It can be concluded that the maximum and minimum levels of consumption of alcoholic beverages $\mathrm{AB}$ in 158 countries of the world had significant statistical differences in terms of amount and structure. It should be noted that the first group included countries mainly with Christian faith. Group 2 - countries, mainly of the Muslim faith (List of countries 1 ). In the $1^{\text {st }}$ group and the $2^{\text {nd }}$ group of countries the «Prohibition» periodically operated. It is accompanied by a decrease in mortality from alcoholism, cardiovascular diseases and other NCDs [28,29].

The recreational use of psychoactive substances has been known since ancient times. Preferences and prohibitions depend on cultural traditions. Health issues from psychoactive use substances remain the subject of scientific discussions $[18,30]$. It is known that alcohol is a source of energy $(7.1 \mathrm{~g} / \mathrm{kcal})$. The energy content of 1 gram of alcohol is $29 \mathrm{~kJ}$ (7.1 kcal). Alcohol consumption can lead to excess weight [30-34]. Predictors of MS and alcohol consumption in Group 1 of countries were higher than Group 2 ( $\mathrm{p} \leq 0.001)$. But the burden of diabetes mellitus (CD1 + CD2) and nephritis in men and women in Group 1 countries was significantly lower than Group 2 ( $\mathrm{p} \leq 0.001)$. Our results contradict the literature data [35-40]. Group 1 had a higher burden of pancreatic cancer and alcoholism than Group 2. This correlates with high rates of rice factors in group 1 countries and literature data [37-39].

An increase in the independent variable $A B$ by 10 grams (MPA) was accompanied by a decrease in the NCD dependent variables by $0.5 \%$; and diabetes mellitus, as well as nephritis by $2 \%(\mathrm{p} \leq 0.001)$. However, an increase in the independent variable $\mathrm{AB}$ by 10 grams was accompanied by an increase in the burden of the dependent variables for pancreatic cancer and alcoholism by $5 \%$ and $3 \%$, respectively $(\mathrm{p} \leq 0.001)$. Our results, using two statistical methods, indicate that the effects of risk factors on NCD disease can be positive and negative. According to a number of authors, insulin resistance in T2DM occurs in the muscles of thin people predisposed to diabetes [41]. According to the authors, this insulin resistance is responsible for the excessive accumulation of fat associated with T2DM. This early muscle insulin resistance is the etiology of hyperlipidemia and excess fat accumulation, typical for type 2 diabetes [41]. Diabetes is a general term for a group of metabolic disorders. They affect the ability of the human body to use glucose for energy. This serious problem threatens the quality of human life [42]. The etiology of diabetes is still a mystery. To our knowledge, the burden of diabetes depends solely on the latitude and level of ultraviolet radiation [43]. At the same time, the burden of cardiovascular disease is related to economic status and does not depend on latitude [44]. Hormone-dependent cancers and MS are dose dependent on the income of countries $[45,46]$.

The fight against obesity has led to the development of effective pharmacological and surgical methods. Bariatric surgery
(BS), or weight loss surgery. Research shows HD causes significant weight loss, reduced food addiction, diabetes recovery, and a $23 \%$ reduction in mortality from $40 \%$. BS revealed an unexpected phenomenon called by the authors «reward deficit transfer» [47]. Some patients after BS showed a craving for psychoactive substances, including alcohol [47,48]. Preclinical and clinical studies have shown a decrease in dopamine receptors in the brain. Etiotropic agents have been tested to correct these transfers [4751].

\section{Conclusion}

Studies have shown that the maximum and minimum daily consumption of alcoholic beverages (AB) in the diet in 158 countries of the world in 2004 differed 108 times and amounted to 342 and 2.6 grams per person without regard to gender and age $(\mathrm{p} \leq 0.001)$. In group 1 (20 countries) with high $\mathrm{AB}$ compared to group 2 (20 countries) with low AB, GDP was 14 times higher $(p \leq 0.001)$. In group 1, the burden of pancreatic cancer was 3,5 times higher $(\mathrm{p} \leq 0.001)$ and 12 times the burden of alcoholism was higher $(\mathrm{p} \leq 0.001)$.

However, in group 1 countries, the burden of diabetes mellitus was 2,5 times lower and the burden of nephritis was 7 times lower $(\mathrm{p} \leq 0.001)$. In countries with maximum $A B$, predictors of metabolic syndrome - MS (\% of men and women in the country with MS disorder) were 2 times higher $(\mathrm{p} \leq 0.001)$. In addition, Group 1 countries were 3 times higher predictors of MS. Gender differences in the studied characteristics are noted.

\section{Conflict of interest}

The authors have no conflicts of interest

\section{Acknowledgments}

Authors are grateful for constant consultations Alexander Nemtsov, M.D. National Center for Addiction Medicine.

\section{References}

1. Lapuente M, Estruch R, Shahbaz M, Casas R (2019) Relation of Fruits and Vegetables with Major Cardiometabolic Risk Factors, Markers of Oxidation, and Inflammation. Nutrients 11(10): 2381.

2. Nguyen TT, Hoang MV (2018) Non-communicable diseases, food and nutrition in Vietnam from 1975 to 2015: the burden and national response. Asia Pac J Clin Nutr 27(1): 19-28.

3. Khemthong K, Turnbull N, Suwanlee SR, Peltzer K (2020) The Prevalence of Alcohol and Tobacco Use Associated Risk Factor of Noncommunicable Diseases in Si Sa Ket Province, Thailand. Stud Health Technol Inform 270: 1407-1408.

4. NCD Countdown 2030 collaborators (2018) NCD Countdown 2030: worldwide trends in non-communicable disease mortality and progress towards Sustainable Development Goal target 3.4. NCD Countdown 2030 collaborators. Lancet 392(10152): 1072-1088.

5. Di Cesare M, Khang YH, Asaria P, Blakely T, Cowan MJ, et al. (2013) Inequalities in non-communicable diseases and effective responses. Lancet NCD Action Group Lancet 381(9866): 585-597. 


\section{Current Research in Diabetes \& Obesity Journal}

6. Idowu A, Fatusi AO, Olajide FO (2016) Clustering of behavioural risk factors for non-communicable diseases (NCDs) among rural-based adolescents in south-west Nigeria. Int J Adolesc Med Health 30(1).

7. Kolb R, Sutterwala FS, Zhang W (2016) Obesity and cancer: inflammation bridges the two. Curr Opin Pharmacol 29: 77-89.

8. Cox AJ, West NP, Cripps AW (2015) Obesity, inflammation, and the gut microbiota. Lancet Diabetes Endocrinol 3(3): 207-15.

9. Saad MJ, Santos A, Prada PO (2016) Linking Gut Microbiota and Inflammation to Obesity and Insulin Resistance. Physiology (Bethesda) 31(4): 283-293.

10. Izaola O, De Luis D, Sajoux I, Domingo JC, Vidal M (2015) [Inflammation and obesity (lipoinflammation)]. Nutr Hosp 31(6): 2352-2358.

11. Iyengar NM, Gucalp A, Dannenberg AJ, Hudis CA (2016) Obesity and Cancer Mechanisms: Tumor Microenvironment and Inflammation. J Clin Oncol 34(35): 4270-4276.

12. Fioravante M, Bombassaro B, Ramalho AF, Dragano NR, Morari J, et al. (2017) Inhibition of hypothalamic leukemia inhibitory factor exacerbates diet-induced obesity phenotype. J Neuroinflammation 14(1): 178.

13. Zheng Y, Ley SH, Hu FB (2018) Global aetiology and epidemiology of type 2 diabetes mellitus and its complications. Nat Rev Endocrinol 14(2): 88-98.

14. Engler PA, Ramsey SE, Smith RJ (2013) Alcohol use of diabetes patients: the need for assessment and intervention. Acta Diabetol 50(2): 93-99.

15. Knott C, Bell S, Britton A (2015) Alcohol Consumption and the Risk of Type 2 Diabetes: A Systematic Review and Dose-Response Metaanalysis of More Than 1.9 Million Individuals From 38 Observational Studies. Diabetes Care 38(9): 1804-1812.

16. Kerschbaum E, Nüssler V (2019) Cancer Prevention with Nutrition and Lifestyle. Visc Med 35(4): 204-209.

17. Pietraszek A, Gregersen S, Hermansen K (2010) Alcohol and type 2 diabetes. A review. Nutr Metab Cardiovasc Dis 20(5): 366-375.

18. Golan R, Gepner Y, Shai I (2010) Wine and Health-New. Evidence. Eur J Clin Nutr. 72(Suppl 1): 55-59.

19. David F (2020) [Which diet is appropriate for patients with diabetes mellitus?]. Ther Umsch 77(7): 302-311.

20. World Health Organization. The global burden of disease: 2004 update. Geneva (2008) WHO.

21. United Nations Department of Economic and Social Affairs / Population Division (2009) World Population Prospects 2008.

22. World Health Organization (2004) Average daily ambient ultraviolet radiation (UVR) level. World Health Data Platform / GHO / Indicator Metadata Registry List Average daily ambient ultraviolet radiation (UVR) level.

23. World Population Prospects United Nations (2005-2010).

24. Bhaven NS (2009) Academic Patents and Access to Medicines in Developing Countries. Am J Public Health 99(1): 9-17.

25. World Happiness Report UN Sustainable Development Solutions Network 2021 Changes in the happiness index of the countries of the world from 2008-2012 to 2017-2019.

26. Global Health Observatory (GHO) data (2008) Indicator and Measurement Registry version 1.7.0 $\mathrm{BMI} \geq 25$; total cholesterol $\geq$ 5.0; blood glucose 7.0; insufficiently active. // WHO (World Health Organization) Percentage of defined population Program Country 2008.
27. Food and Agriculture Organization of the United Nations. Food Balance Sheets 2003-05.

28. Nemtsov AV (1998) Alcohol-related harm and alcohol consumption in Moscow before, during and after a major anti-alcohol campaign. Addiction 93(10): 1501-1510.

29. Nemtsov AV, Razvodovsky YE (2016) Russian Alcohol Policy in False Mirror. Alcohol Alcohol 51(5): 626-627.

30. Traversy G, Chaput JP (2015) Alcohol Consumption and Obesity: An Update. Curr Obes Rep 4(1): 122-130.

31. Suter PM (2005) Is alcohol consumption a risk factor for weight gain and obesity? Crit Rev Clin Lab Sci. 42(3): 197-227.

32. Klop B, do Rego AT, Cabezas MC (2013) Alcohol and plasma triglycerides. Curr Opin Lipidol 24(4): 321-326.

33. Yeomans MR (2010) Alcohol, appetite and energy balance: is alcohol intake a risk factor for obesity? Physiol Behav 100(1): 82-89.

34. Sayon OC, Martinez GMA, Bes RM (2011) Alcohol consumption and body weight: a systematic review. Nutr Rev 69(8): 419-431.

35. Keefe JHO, Bhatti SK, Bajwa A, DiNicolantonio JJ, Lavie CJ (2014) Alcohol and cardiovascular health: the dose makes the poisonor the remedy. Mayo Clin Proc 89(3): 382-393.

36. Qamar N, Castano D, Patt C, Chu T, Cottrell J, et al. (2019) Meta-analysis of alcohol induced gut dysbiosis and the resulting behavioral impact. Behav Brain Res 376: 112196.

37. Kumar S, Behl T, Sachdeva M, Sehgal A, Kumari S, et al, (2021) Implicating the effect of ketogenic diet as a preventive measure to obesity and diabetes mellitus. Life Sci 264: 118661.

38. Clark M, Hoenig M (2016) Metabolic Effects of Obesity and Its Interaction with Endocrine Diseases. Vet Clin North Am Small Anim Pract 46(5): 797-815.

39. Saklayen MG (2018) The Global Epidemic of the Metabolic Syndrome. Curr Hypertens Rep 20(2): 12.

40. DeNicola E, Aburizaiza OS, Siddique A, Khwaja H, Carpenter DO (2015) Obesity and public health in the Kingdom of Saudi Arabia. Rev Environ Health 30(3): 191-205.

41. Malone JI, Hansen BC (2019) Does obesity cause type 2 diabetes mellitus (T2DM)? Or is it the opposite? Pediatr Diabetes 20(1): 5-9.

42. Befiker A, Melese S, Minale F (2021) Assessment of Self-Care Dietary Practice and Associated Factors among Diabetic Patients in Bethel Teaching General Hospital. Addis Ababa, Ethiopia, EC Pharmacology and Toxicology 9(7): 53-71.

43. Lyudmila AR, Dariya AR (2021) Dietary Patterns and Economic and Geographic Risk Factors for the Burden of Diabetes Mellitus (Observational Study). EC Diabetes and Metabolic Research 5(4): 8296.

44. Lyudmila AR, Daria AR (2021) Analysis of Dietary Patterns and Economic and Geographic Risk Factors for the Burden of Cardiovascular Disease. J Cardio Res \& Rep 5(2).

45. Radkevich LA, Radkevich DA (2018) Determinants of the Happiness Index, Life Expectancy, Incidence and Dietary Patterns in Different Countries. Journal of Obesity and Chronic Diseases 26-36.

46. Radkevich LA, Radkevich DA (2018) Dietary Patterns and Oncological Morbidity in European and Mediterranean Countries. Clin Oncol Res 1(2): 1006.

47. Blum K, Bailey J, Gonzalez AM, Oscar BM, Liu Y, et al. (2011) NeuroGenetics of Reward Deficiency Syndrome (RDS) as the Root Cause of 


\section{Current Research in Diabetes \& Obesity Journal}

"Addiction Transfer": A New Phenomenon Common after Bariatric Surgery. J Genet Syndr Gene Ther 2012(1): S2-001.

48. Orellana ER, Covasa M, Hajnal A (2019) Neuro-hormonal mechanisms underlying changes in reward related behaviors following weight loss surgery: Potential pharmacological targets. Biochem Pharmacol 164 106-114.
49. Ammori BJ, Skarulis MC, Soran H, Syed AA, Eledrisi M, et al. (2020) Medical and surgical management of obesity and diabetes: what's new? Diabet Med 37(2): 203-210.

50. Nance K, Acevedo MB, Pepino MY (2020) Changes in taste function and ingestive behavior following bariatric surgery. Appetite 146: 104423.

Your next submission with Juniper Publishers
will reach you the below assets
- Quality Editorial service
- Swift Peer Review
- Reprints availability
- E-prints Service
- Manuscript Podcast for convenient understanding
- Global attainment for your research
- Manuscript accessibility in different formats
( Pdf, E-pub, Full Text, Audio)
- Unceasing customer service
Track the below URL for one-step submission
https://juniperpublishers.com/online-submission.php

